\title{
NEW FELLOWS OF THE ROYAL SOCIETY
}

THE following were elected fellows of the Royal Society on March 18 :

Sir Shanti Swarupa Bhatnagar, director of scientific and industrial research, India. Distinguished for his numerous contributions to physical chemistry, more especially to magneto-chemistry. As professor of chemistry in the University of the Punjab he built up a flourishing school of research. Since the outbreak of war he has organized a new scientific department of the Government of India.

Prof. P. A. Buxton, director, Department of Entomology, London School of Hygiene and Tropical Medicine. Distinguished for his researches in medical entomology with special reference to the conditions under which insects responsible for the transmission of diseases multiply and the measures which must accordingly be adopted for their control.

Prof. I. DE B. DALY, professor of physiology, Edinburgh. Distinguished as an originator of essential items of modern physiological technique, and for his important contributions to the physiology of the circulation in the lungs and the bronchial tubes.

Vrce-Admiral Sir A. Edgetr, R.N., hydrographer of the Royal Navy. Distinguished for the organization and encouragement of work in tidal research, in determining gravity at sea and in magnetic and electric survey of the oceans.

DR. A. J. EwINs, director of research, May and Baker, Ltd. Distinguished for his ehemical and biochemical researches. His work in organizing an industrial research laboratory has led to the production of some of the most important synthetic remedies in recent years.

DR. A. FELIX, bacteriologist, Lister Institute. Distinguished for his contributions to serology and bacteriology. $\mathrm{He}$ is particularly associated with the Weil-Felix reaction for the diagnosis of typhus fever and with the antigenic analysis of bacteria.

Prof. Alexander Fleming, professor of bacteriology, St. Mary's Hospital, London. Distinguished for his contributions to bacteriology, immunology and chemotherapy. His work includes the very important discoveries of lysozyme and penicillin.

DR. J. J. Fox, Government Chemist. Distinguished for his application of physical methods to the discovery of the structure of chemical substances and for his work on now analytical methods and chemical processes.

Dr. W. M. H. Greaves, Astronomer Royal for Scotland. Distinguished for his contributions to stellar spectro-photometry and for the discussion of the colour temperatures of early type stars.

Dr. S. C. Harland, plant breeder. Distinguished for his contributions to the study of genetics and especially of the cotton plants. His researches have not only been of practical value for tropical agriculture, but also have led to important advances in fundamental aspects of evolutionary theory.

Prof. G. A. R. KoN, research professor of chemistry at the Royal Cancer Hospital. Distinguished for his researches in organic chemistry. During recent years his work on the polyterpenes has provided the basis for a number of important developments.

DR. A. MCCANCE, director and general manager, Messrs. Colville's, Ltd., Motherwell. Distinguished for his work in the steel industry and particularly for his applications of physical chemistry to the processes of steel making.

Prof. Wilder Penfield, director of the Montreal Neurological Institute. Distinguished for his researches in neuro-histology and as a neuro-surgeon.

Dr. G. E. PILGRIM, formerly superintendent of the Geological Survey of India. Distinguished for his contributions to the geology of India, particularly in the field of Tertiary stratigraphy, and for his researches in vertebrate palæontology.

Dr. R. E. Stradling, chief adviser, Research and Experiments Department, Ministry of Home Security. Distinguished for his researches on the properties of building materials and for his direction of the Building and Road Research Stations and of researches relating to civil defence.

Dr. C. Sykes, superintendent of the Metallurgy Department of the National Physical Laboratory. Distinguished both for his fundamental scientific advances in the study of alloys and for the practical improvements which he has effected in various branches of metallurgy.

Prof. J. L. SynGe, professor of applied mathematics, Toronto. Distinguished for his contributions to mathematics, particularly to the geometry of dynamics, the theory of relativity, hydrodynamics and electricity.

Prof. G. F. J. Thmple, professor of mathematics, King's College, London. Distinguished for his contributions to mathematical physics, particularly to quantum theory, relativity and mechanics.

Dr. A. L. DU TorT, lately consulting geologist to the De Beers Consolidated Mines. Distinguished for his contributions to the geology and petrology of South Africa, particularly his work on the Karroo system and his comparative study of the equivalent succession of South America.

Prof. Solly ZuCkarman, professor of anatomy, University of Birmingham. Distinguished for his studies on the morphology and relationship of the Primates and on their reproductive physiology. He has also made outstanding contributions to the study of social behaviour in the lower Primates.
The election of Sir Shanti Swarupa Bhatnagar to the fellowship of the Royal Society is a well-deserved recognition of his distinguished contributions to the advancement of science. The event is indeed a signal one, for he is the first Indian chemist to receive this high honour.

As a young Indian M.Sc. graduate he went in 1919 to Prof. F. G. Donnan's laboratory at University College, London, where he carried out a series of investigations on the stability and inversion of emulsions, obtaining the D.Sc. degree of the University of London in 1921. Returning to India, he went first to the Benares Hindu. University, and, in 1924, to the University of the Punjab at Lahore, where he was appointed to the professorship of physical chemistry. Here he began to build up a university school of physico-chemical teaching and research, which through his own personal investiga- 